\title{
Protecting documents against disasters and theft: the challenge before the public libraries in KwaZulu-Natal, South Africa
}

\author{
Patrick Ngulube' and Lindiwe Magazi ${ }^{2}$ \\ Information Studies Programme, School of Sociology and Social Studies, University of KwaZulu-Natal, \\ P/Bag X0I, Scottsville, 3209, Pietermaritzburg, South Africa \\ ngulubep@ukzn.ac.za, magazil@kznlr.kzntl.gov.za
}

Received: $24^{\text {th }}$ May 2006

Accepted : $14^{\text {th }}$ August 2006

All forms of documentary materials are prone to disasters and theft. Security and disaster management are keys to the protection of library materials from theft and risks. However, librarians often overlook disaster preparedness and security control yet they are fundamental aspects of preservation management as they make it possible for people to have access to library materials, and to respond to and recover from disasters. A cross-sectional survey carried out between December 2005 and February 2006 in public libraries of KwaZulu-Natal revealed that the libraries were not adequately prepared for protecting documents against disasters and theft. Furthermore, most of the public libraries did not have disaster plans, adequate procedures for disaster response and recovery, satisfactory theft management strategies and sufficient staff with disaster management knowledge and skills.

Keywords: Disaster Preparedness, preservation, public libraries, KwaZulu-Natal, security control

\section{Background and context}

Libraries are vulnerable to a variety of disasters and security risks. Security and disaster management are keys to the protection of library materials from theft and disasters. Many disasters are difficult to predict or avoid except through taking preventive measures. In that regard, the best defence is a plan for effective response (Ngulube 2003b). Disaster planning is the major component of any disaster preparedness strategy because it prepares institutions to respond quickly to emergencies. Put differently, disaster planning provides details of preventative and preparatory measures that may reduce the impact of disasters and help an organization to continue carrying out its normal business activities with few disruptions.

Although disaster preparedness in one of the key elements of a preservation strategy (Matthews and Feather 2003:xv; Morrow 2000: I I), it is often overlooked by librarians (Buchanan 2000: 159). In addition to large-scale emergencies, librarians should also be aware of the danger to their collections from theft and vandalism. Adequate protection from theft and vandalism is fundamental to safeguarding the valuable materials in libraries (Ngulube 2003b:63).

While a number of studies on disaster management and security control have been conducted in the developed world, there is scant evidence of such research in sub Saharan Africa (SSA) in general and South Africa in particular. Morgan and Smith(1997) made a similar observation about ten years ago, and the situation has not really changed. The study by Alegbeleye (1993) does not fill that lacuna because it does not have an African perspective as claimed by its title. In fact, it is geographically limited to Nigeria and Kenya. However, available literature seems to suggest that SSA is gradually becoming concerned with matters related to disaster management and security control (Abareh 200I; Akussah and Fosu 200I; Alegbeleye 1993; Andiku 2005; Coates 1993; Fosu and Akussah 2002; Hlabangaan 2006; Ngulube 2003b; Ngulube 2005).

As was the case in Europe a few years back (see Wellheiser and Scott 2002:4), the basic principles of disaster management and security control are gradually becoming understood in SSA, but their application is very limited. In that regard, the current study sought to establish the level of understanding and application of the principles of disaster management and security control by librarians working in the public libraries of KwaZulu-Natal (KZN), and identifying best practice. The study was guided by the following questions:

- What are the current disaster management and security control practices in public libraries in KZN?

- What strategies are being used to deal with disaster management and security needs in public libraries in KZN?

- How widespread and pervasive is the problem of theft in public libraries in KZN?

- How knowledgeable is the staff in disaster management and security control?

- What recommendations can be made for disaster management and security control in public libraries in KZN?

I. Patrick Ngulube (PhD) is Associate Professor, Information Studies Programme, University of Kwazulu Natal, South Africa

2. Lindiwe Magazi is a masters student, Information Studies Programme, School of Sociology and Social Studies, University of KwaZuluNatal, South Africa 


\section{Scope and definitions}

The study investigated disaster management and security control in public libraries of KZN. At the time of the study, the libraries were divided into four regions, namely, Coast, Midlands, North and South. There were 164 public libraries; however, only a sample of the population was studied.

Security and protection of documents includes actions that are taken to discourage crime and to prevent or minimise damage to the library collections (Ngulube 2005:19). Security control protects items against theft or deliberate or unintentional damage and destruction. Security control is an important aspect of disaster planning (Matthews 2003). On the other hand, many definitions of disasters have been offered in the context of information management (Alegbeleye 1993:5; Eden and Matthews 1996:6; Sturges 1999:167). Following Eden and Matthews (1996:4), this article defines a disaster as an unexpected event that may drastically threaten the lives of humans or damage buildings, destroy the information infrastructure, disrupt services, and render documentary materials inaccessible to users.

Disaster management techniques assist in determining the likelihood of disasters and lessening their consequences. Disaster planning provides a blueprint for dealing with disaster management activities (Mansell 2003; Muir and Shenton 2002). Risk management processes may assist in developing disaster preparedness plans (Eden and Matthews 1996:7; Ngulube 2005:19). A disaster preparedness plan is 'a document which describes the procedures devised to prevent and prepare for disasters, and those proposed to respond to and recover from disasters when they occur' (Lyall 1995: 103). Disaster management plans are important because they have the possibility of (Mansell 2003: 14; Ogden 1996):

- Reducing disruption of normal operations;

- Raising awareness of the importance of being prepared;

- Providing for training for personnel in emergency procedures; and

- Coordinating disasters by providing clear procedures and assigning people's roles and responsibilities.

Some of the events that may pose risks to documentary materials include hurricanes, tornadoes, flash flooding, earthquakes, forest fires, volcanic eruptions, power outages, leaking roofs and pipes, chemical spills, theft, arson, bomb threats, and acts of war and terrorism (Eden and Matthews 1996:6; Harvey 1993: I 19; Ngulube 2003b:58). Although Law (1999:6) further categorised disasters as predictable and unpredictable, some of the literature (Alegbeleye 1993:5; Matthews 2003:3; Ngulube 2003b:59) classifies them as either natural or human-made, (that is, in the most generic sense). This characterisation is used in the next section to document examples of events that have exposed documentary materials to risks worldwide.

\section{The writing is on the wall: chronicling selected cases on disasters}

The list of both natural and human-made disasters that have affected documentary materials worldwide is endless. The following examples are used to illustrate that disasters are part of the reality of managing documentary materials and librarians must be prepared to deal with them. No criteria were used to select these case studies except that the authors were familiar with them. If the readers were able to relate one or two of the given examples to their own situations, then we would have achieved our objectives in highlighting these cases.

Bombs destroyed many libraries in Europe and Japan during the Second World War (Van der Hoeven and Van Albada 1996). Public libraries were reduced from 53 in 1975 to $\mathrm{II}$ in $200 \mathrm{I}$ as a result of the civil war in Angola (Ramos 200 I:97). Communal riots in Lahore (Pakistan) in 1948 led to the destruction of two of the largest libraries in India (Van der Hoeven and Van Albada 1996). In April 1986, a suspected act of arson destroyed Los Angeles Central Library, the United States's third largest public library (Butler 1986). Approximately 400,000 volumes out of a total of 2, I million were completely destroyed. In February 1988, a fire caused what has been called 'the biggest single library disaster' in the $19^{\text {th }}$ Century at the USSR Academy of Sciences Library in Leningrad (Waters 1990). About 3, 6 million books were seriously damaged and 400,000 newspapers and scientific periodicals were lost. On II September 200 I terrorists bombed the World Trade Centre and the Pentagon Library in the US, destroying records, books and other documentary materials (Harrison 2002). The 'National Library and Archives, a priceless treasure of Ottoman historical documents including the royal archives of Iraq, were turned to ashes in 3000 degrees of heat' on 14 April 2003 during the United States' invasion of Iraq (Fisk 2003).

An earthquake caused serious damage to the National and University Library of Macedonia (Yugoslavia) in July 1963 (Van der Hoeven and Van Albada 1996). As a result of the Arno flood of November 1966, the basement of the Bibliotheca Nazionale Centrale in Italy I,200,000 volumes and pamphlets were damaged (Feather 1991). Flash floods hit Mozambique's districts of Xai-Xai, Chokwe and Guija during the year 2000 causing substantial damage to documentary materials (Maúngue, Mahumane and Mangue 2003). In January 2004 Cyclone Heta flattened the Cultural Centre and severely damaged the National Library on the Island of Niue (PABRICA 2004). In August 2005, Hurricane Katrina completely destroyed the Martin Luther King branch of the New Orleans Library, with nothing salvageable (American Library 
Association 2005). A tsunami hit Sri Lanka in December 2004 affecting 62 of the 950 public libraries, with 28 libraries being entirely destroyed (Amarasiri 2005:309).

\section{Method and procedure}

Using the survey design, this study assessed disaster preparedness and security control in public libraries in KZN. The survey method, with a self-completion questionnaire as the major tool for data collection was deemed to be appropriate as it was successfully used by Alao (2003), Eden, Feather and Matthews (1994), Fosu and Akussah (2002) and Ngulube (2003a) to assess preservation needs in libraries and archives. Burrows and Cooper (1992) also used the same data collection techniques in determining the extent of theft and mutilation of library books in the United Kingdom. The questionnaire used in the survey was adapted from Clements (1987), Morrow (2000) and Ngulube (2003a).

The cross sectional survey was done between December 2005 and February 2006 using a sample of the target population comprising 164 public libraries. The sub-set to be studied was obtained by using tables for determining sample sizes for different sized universes at a 95\% level of certainty and a margin of error of 5\% (Payne and Payne 2004:203). The sample frame was obtained from the database of the KwaZulu-Natal Provincial Public Library and Information Service. The four regions under which the libraries fell provided a basis for the strata. Proportional stratified random sampling was used in order to achieve greater representativeness in the sample of the population. The random numbers were generated using Microsoft Excel ${ }^{\circledR}$. Table I gives the sizes of the population and sample, strata constituting the population and response rates per stratum.

Table I Universe, sample size and response rates per stratum

\begin{tabular}{ccccc}
\hline \multirow{2}{*}{ Universe } & \multirow{2}{*}{ Sample size } & Stratum & \multicolumn{2}{c}{ Response rate per stratum } \\
\cline { 3 - 4 } & & Expected & Observed \\
\hline & Coast & $38(32.93 \%)$ & $17(14.66 \%)$ \\
& Midlands & $27(23.17 \%)$ & $12(10.34 \%)$ \\
& North & $25(21.34 \%)$ & $11(9.48 \%)$ \\
& & $26(22.56 \%)$ & $10(8.62 \%)$ \\
& & South & $116(100 \%)$ & $50(43.1 \%)$ \\
\hline
\end{tabular}

After successfully pre-testing the questionnaire, it was dispatched to the selected sample with a covering letter explaining the importance of the study, that participation was voluntary and that the collected data was going to remain confidential and was only going to be used for the purpose of the study. The response rate was $16 \%$ after four weeks of posting the questionnaire with an enclosed addressed and stamped return envelope. A second questionnaire was sent to those libraries that had not replied by 26 January 2006. That increased the response rate to $30 \%$. Follow-up telephone calls were made to encourage the participants to respond to the questionnaire. As a result, the response rate went up to 43. $1 \%$ by the end of February 2006.

The survey data should be treated with some caution. The sample that was studied was quite small as a result of a low response rate of $43.1 \%$. According to Babbie and Mouton (2001:26I) the consensus in survey research was that a response rate of $50 \%$ was considered adequate for analysis, while $60 \%$ was good and $70 \%$ was considered very good. However, authorities are not agreed on what constitutes an adequate response rate. Shipman (1997:63) argued that, although Hite (1994) used a response rate of $4.5 \%$ in his study, the normal figure is between $20 \%$ and $30 \%$. Previous researchers in the field of preservation achieved varying response rates. For instance, Mbaye (1995:4I) had a response rate of $35.71 \%$ from 28 institutions. In 1986 Clements (1987) carried out an international study to assess the state of the world patrimony and got a response rate of $49 \%$. Murray (2002:55) surveyed 17 institutions in South Africa and had a response rate of $64.71 \%$.

Nonetheless, the researchers in the current study were given the confidence to analyse the results and present their findings despite a low response because it is becoming apparent that response rates in survey research are declining (Groves, Cialdini and Couper 1992). According to Rogelberg and Luong (1998), response rates for mailed questionnaires have dropped to $50 \%$ or less and they will continue to decline over the years. On the other hand, Payne and Payne (2004:222) pointed out that the typical response rate for self-completion surveys was $33 \%$. The fact that the responses that we received resembled the original sample made us proceed with the analysis and to make some generalisations about the findings. Item nonresponse was not observed in the current study.

SA JnI Libs \& Info Sci 2006, 72(3) 
The low response rate may either be attributed to the fact that librarians in public libraries of KZN did not attach a lot of importance to disaster management or they were not familiar with the issues that were presented in the questionnaire. Indeed, three respondents said that the questionnaire was more suitable to legal deposit libraries and archival institutions than public libraries, although they went on to complete the questionnaire in a very informative way.

Furthermore, the questionnaires were probably sent during the wrong time of the year, when librarians were planning to go on holiday or were preparing for the activities of the New Year. With hindsight from our experience, we agree with Leedy and Ormrod (2005:193) that researchers should not send out questionnaires during the 'peak holiday and vacation times, such as mid-December through early January'.

\section{Results and discussions}

The data presented in this study are not associated with any particular public library. To encourage full and frank participation, respondents were promised that their institutional data would not be individually identifiable. The results are presented and discussed in order to answer the research questions posed above. First the current situation relating to disaster management and security control in public libraries of KZN is discussed. Then we turn to disaster management strategies used by the public libraries, followed by the problem of theft in libraries. A presentation of the findings of the skills and knowledge of staff in relation to disaster management winds up this section.

4.1 Current situation relating to disaster management and security control in public libraries of KwaZulu-Natal Table 2 summarises the current disaster management practices in public libraries of KZN. Table 3 deals with security related matters. It is evident from Table 2 that $74 \%$ of the libraries had suffered some damage in one way or another. Twenty-two libraries attributed the damage to leaking roofs, six to flooding and nine to vandalism. That underscores the fact that public libraries of KZN should take immediate steps to protect their collections from various risks.

Lack of building maintenance is one of the causes of many library disasters that have been reported in the literature (Morgan and Smith 1997: 64). For instance, blocked gutters may lead to roof leaks and flooding which may be detrimental to the safety of library materials. Thus, buildings should be inspected and maintained regularly in order to identify risks that may pose danger to people and library collections. Morgan and Smith (1997:66) discovered that $10(83 \%)$ libraries in the Greater Cape Metropolitan Area carried out building maintenance inspections, albeit on an irregular basis. The current study discovered that $35(70 \%)$ public libraries were subject to regular technical maintenance, which is highly commendable. Some of the libraries were not regularly maintaining their buildings because their buildings were still very new, and in some instances the libraries were not the sole tenants. As a result they had limited control over the buildings' maintenance programmes. However, it was pleasing to note that all the respondents were aware of the fact that buildings should be maintained regularly in order to guarantee the safety of library materials and people.

Table 2 Disaster management practices in public libraries $(\mathrm{N}=50)$

\begin{tabular}{lcc}
\hline Disaster management practices & \multicolumn{2}{c}{ Frequency } \\
\cline { 2 - 3 } Fire extinguishers available in the library building & Yes & - \\
Fire extinguishers were updated and operable & $40(100 \%)$ & $7(14 \%)$ \\
Library collection ever suffered some damage & $37(74 \%)$ & $13(26 \%)$ \\
Building subject to regular technical maintenance & $35(70 \%)$ & $15(30 \%)$ \\
There was a list of members to be called in an emergency & $28(56 \%)$ & $22(44 \%)$ \\
Incidents reports regularly compiled and reviewed & $18(36 \%)$ & $32(64 \%)$ \\
Existence of disaster preparedness plans & $14(28 \%)$ & $36(72 \%)$ \\
Co-operation with the fire department & $14(28 \%)$ & $36(72 \%)$ \\
Had a list of services needed in an emergency & $12(24 \%)$ & $38(76 \%)$ \\
Library had a fire detection system & $11(22 \%)$ & $39(78 \%)$ \\
Existence of a fire suppression system & $11(22 \%)$ & $39(78 \%)$ \\
Fire detection system connected to a central monitoring facility & $10(20 \%)$ & $40(80 \%)$ \\
Staff trained in procedures to be followed in case of a disaster & $5(10 \%)$ & $45(90 \%)$ \\
Carried out simulated disaster drills & $5(10 \%)$ & $45(90 \%)$ \\
Collaboration among public libraries in KwaZulu-Natal & - & $50(100 \%)$ \\
Co-operation with other cultural institutions on disasters & - & $50(100 \%)$ \\
\hline
\end{tabular}


All libraries had fire extinguishers and the number they had varied from two to six. The majority of the libraries had three fire extinguishers. Thirty five (70\%) libraries reported that fire extinguishers were inspected annually and six (I2\%) libraries never inspected them. The remaining nine (18\%) libraries inspected and maintained them on an ad hoc basis. Twenty (40\%) libraries also revealed that staff had been trained in the use of fire extinguishers and knew how to operate them. On the other hand, $30(60 \%)$ were not familiar with handling fire extinguishers. The same respondents did not know the most effective type of fire extinguishers to use to contain different types of fire.

Training of staff in using fire equipment seems to be overlooked in many libraries. A study in Ghana revealed that $99 \%$ of the staff knew the location of the fire extinguisher and 67\% did not know how to operate them (Andiku 2005:78). Staff should be trained in the use of safety equipment such as fire extinguishers, as advised by Matthews and Eden (1996:33). Fire extinguishers offer the first line of defense in the event of a fire. A small fire that the staff may possibly deal with can cause catastrophic damage if not contained at an early stage. Thus basic knowledge of the use of fire fighting equipment becomes very important in safeguarding people and documents. Equally, fire extinguishers should be regularly tested to ensure that they are operable in the event of a fire.

Librarians and fire fighters should work together so that they can draw up fire safety measures for library collections as well as determine the level of protection required by the library (Matthews 2003). Co-operation with the local fire department was limited, as illustrated in Table 2. Eight (16\%) respondents said the fire department visited the library to carry out inspections. The fire department trained staff in fire prevention and fighting techniques in $12(24 \%)$ libraries. According to Holden (2004) the most important conclusion remains that without the co-operation and support of the fire service at all times, the chances of successfully salvaging collections from a burning building are minimal.

It is evident from Table 2 that resource sharing and collaboration among public libraries in KZN was very limited. Furthermore, all respondents reported that they did not collaborate with other cultural institutions such as art galleries, libraries and museums in order to get assistance in the event of a disaster. Sharing resources in the event of a disaster has proved very successful in Australia (Mansell 2003:37).

Turning to the issues related to security, it was discovered that libraries had experienced theft and vandalism. Forty four (88\%) libraries observed damage to their collections caused by vandalism. On the other hand, 36 (72\%) libraries reported that theft was a major problem they had to deal with in their collection management strategies. The KwaZuluNatal Provincial Public Library and Information Service's Annual Report of 2002 corroborate the fact that theft was a huge problem. The evidence at hand shows that the problem was still persisting.

Some ways of reducing theft in libraries include: closed circuit television cameras (CCTV), intruder alarms, security staffing and security 'tagging' (for example, magnetic strips) (Pybus 1998:5I). Some of gadgets used to minimise theft rely on electric power to work efficiently. The study established that only $10(20 \%)$ libraries had an alternative source of power such as a generator. That means that their library security systems may be rendered ineffective in the event of power cuts, thus exposing library materials to the ever-present danger of theft.

Table 3 summarises some of the security measures that were used to safeguard library materials by the respondents. Such security measures can go a long way to reduce library thefts. Although these measures may not be as effective as chaining books to tables as suggested by Lincoln and Lincoln (1986:xi), they have the possibility of reducing opportunities for theft. Only $12(24 \%)$ libraries reported that they had security standards that informed their practices. Standards ensure that procedures and practices meet certain requirements and that they remain consistent over time.

Table 3 Security control practices in public libraries $(\mathrm{N}=50)$

\begin{tabular}{lcc}
\hline Security control practices & \multicolumn{2}{c}{ Frequency } \\
\cline { 2 - 3 } & \multicolumn{2}{c}{ Yes } \\
\hline Depend on electronic security systems (alarms, CCTV) & $47(94 \%)$ & $3(6 \%)$ \\
Intruder alarm system linked to police or a third party & $44(88 \%)$ & $6(12 \%)$ \\
All keys are accounted for & $33(66 \%)$ & $17(34 \%)$ \\
Security personnel around the clock & $17(34 \%)$ & $33(66 \%)$ \\
Security standards & $12(24 \%)$ & $38(76 \%)$ \\
Entire library stock has magnetic strips & $9(18 \%)$ & $41(82 \%)$ \\
\hline
\end{tabular}

Furthermore, nine (18\%) libraries did not test their alarm systems regularly and 21 (42\%) libraries were not aware of their security response policy. Only one library had one access point, 20 (46\%) libraries had 2 access points, 15 (30\%) had three, four (85\%) had four access points and 3 reported having 6 to 8 access points, (which is unbelievable for the size of many public libraries in the province). All staff members kept keys to the library building in $8(16 \%)$ libraries while 
the librarian or library assistant and caretaker kept the keys to $42(84 \%)$ libraries. Failing to test alarm systems, absence of a clear emergency reaction policy, having numerous access points to the library and lack of limited access to the keys to the library building may seriously compromise the security of library materials.

4.2. Strategies used to deal with disaster management and security needs in public libraries

Prevention, preparedness, response and recovery are recognized as the major components of disaster management processes (Eden and Matthews 1996:6; Mansell 2005:4; Kahn 2003:25). According to Ogden (1996) the foregoing four stages may be divided into three phases as follows:

- before the disaster (preventive or mitigation and preparedness): implementing measures to remove or reduce danger as well as being ready by having identified resources, materials, services and procedures in place to deal with problems when they occur;

- during the disaster (response): knowing how to respond to minimise damage quickly and efficiently; and

- after the disaster (recovery): knowing what to do to recover damaged material.

The results in this section are reported in relation to the above outlined stages. Findings relating to library security are then presented and discussed thereafter.

\subsection{Disaster planning}

Like many countries worldwide, South Africa is concerned with disaster management in general. In that regard, the government passed the Disaster Management Act of 2002 (South Africa 2002). Responsibilities for disaster planning have been assigned to the three tiers of government: national, provincial and local. Although libraries should work hand in glove with local government in disaster management related issues, they should have their own context specific disaster preparedness plans. Table 4 shows that there was very limited liaison between librarians and the local authority's disaster management teams. Some librarians were not even aware of the existence of such a government structure in their locality. Librarians should work closely with the government structures concerned with disaster management so that their libraries may also benefit from the resources that the government makes available for dealing with disasters.

Table 4 Level of awareness of the Disaster Management Act and co-operation with local authorities in disaster management $(\mathrm{N}=50)$

\begin{tabular}{lcc}
\hline \multirow{2}{*}{ Level } & \multicolumn{2}{c}{ Frequency } \\
\cline { 2 - 3 } & Yes & No \\
\hline Aware of the Disaster Management Act of 2002 & $14(28 \%)$ & $36(72 \%)$ \\
Aware of the location of the disaster management centre in the local authority area & $7(14 \%)$ & $43(86 \%)$ \\
Staff have been trained in disaster management by local authority & $2(4 \%)$ & $48(96 \%)$ \\
Staff have been given guidance on disaster management by local authority & $2(4 \%)$ & $48(96 \%)$ \\
Staff have been recruited into local authority's disaster management team & $2(4 \%)$ & $48(96 \%)$ \\
\hline
\end{tabular}

According to Fox (1998:xiv) disaster or emergency preparedness in the field of information management is 'a natural part of responsible custody'. Disaster planning has the possibility of facilitating efficient reaction and speedy recovery in the event of an emergency. Thus, the study also sought information on the existence of formal disaster preparedness plans and the kinds of disasters that the plans covered. The results of the study show that 14 (28\%) public libraries in KZN had a written disaster preparedness and recovery plan and all staff members in those libraries were aware of the existence of the emergency preparedness plans. Although disaster plans existed in 14 libraries, one of them did not have a disaster planning team in place.

The low incidence of disaster plans in public libraries has been widely reported in the literature. A study by Eden, Feather and Matthews (1994) in the UK revealed that only $18.18 \%$ of the public libraries had a disaster control plan. A survey of disaster planning in libraries and archives in England, Wales and Northern Ireland showed that $6.6 \%$ of the institutions had disaster control plans in use (Feather 1991:69). In Ghana, Fosu and Akussah (2002:10) discovered that $11.8 \%$ of the special libraries had disaster plans. A survey in South Africa discovered that very few university and public libraries had disaster plans (Coates 1993:I I). Research conducted by Hlabangaan (2006:58) revealed that selected special, academic and public libraries in Gaborone did not have operational disaster preparedness plans.

Although the literature and the results of this study showed that the level of existence of disaster or emergency plans in libraries is low, Morgan and Smith (1997:66) used a purposive sample to carry out a survey among 12 libraries in the Greater Cape Metropolitan Area and found that $42 \%(5)$ of the libraries had formal disaster plans. The figure appears to be high when reported in percentage terms, but in actual fact there were five libraries with disaster plans. Perhaps it would be useful to carry out a similar study using a relatively larger sample so that researchers may be able to determine 
the extent to which disaster preparedness in the Greater Cape Metropolitan Area does not reflect the general trend in South Africa and worldwide. The fact that a purposive sample was used may also partly explain the results of their study.

Although some public libraries in KZN had individual disaster plans, perhaps there is a need for their plans to be linked to an overall national plan (we doubt if there is any). In fact, all the respondents indicated that they had not received any guidance on disaster management from an organisation at a national or provincial level. Commenting on some of the lessons learnt from the tsunami that hit parts of Asia and Sri Lanka in December 2004, Amarasiri (2005:3 I 3) underscored the need to have an 'effective national plan for libraries' in order to effectively deal with disasters. Similar concerns have been expressed in the United Kingdom (UK), Europe, United States and Australia (Feather and Eden 1997:I).

\subsubsection{Mitigation measures}

Mitigation measures involve preparing personnel and documentary materials for all possible risks and hazards in order to reduce their likelihood of occurring, and to minimise the disruption of normal operations. Identifying potential risks may help to prevent disasters.

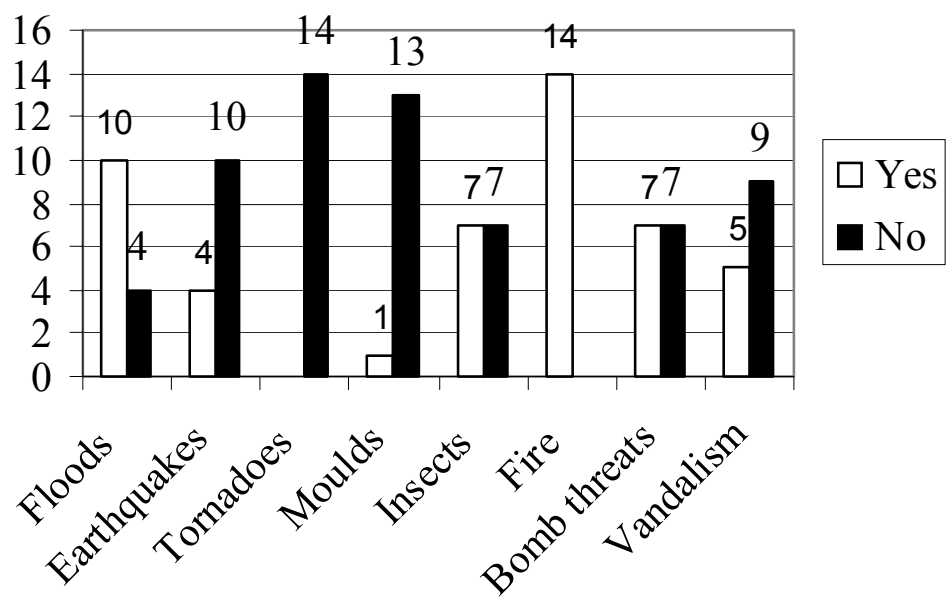

Figure I Disasters covered by plans

The findings revealed that some of the plans did not cover most of the risks that are likely to affect documentary materials (see Fig. I). That means public libraries have not effectively assessed all the risks that may endanger their collections. The identification and assessment of risks help in prioritising the risks as well as reducing the vulnerability of libraries to disasters (Wellheiser and Scott 2002:35).

Recording and reviewing incidents logs also minimises risks to library collections. Results in Table 2 show that only 18 (36\%) libraries maintained incident logs. Incident logs are essential to collection management. They help the library to monitor problematic areas as well as serve as a feedback mechanism in relation to whatever action would have been taken to deal with a problem. However, Table 2 indicates that there were measures in place to minimise the effects of a disaster that may be caused by fire, although the number of formal disaster plans was limited. It is evident from Fig. 2 that some of the disaster plans did not cover flooding, despite the fact that water causes most of the disasters that destroy documentary materials.

\subsubsection{Response measures}

Disaster response is a vital factor of any plan because it has a bearing on the effects of the disaster on people and library collections. Response measures should prioritise the safety of people and salvaging damaged materials. First and foremost, the appropriate response to a disaster is to protect life and limb (Robertson 2005:278). Table 5 indicates that $\mathbf{8 5 . 7 \%}$ of the libraries' disaster plans dealt with the safety of people. However, many disaster plans tend to overlook that aspect in their obsession with protecting documents. Documentary materials should occupy the second position in disaster management priorities. 
Table 5 Aspects dealt with in disaster plan $(n=14)$

\begin{tabular}{lcc}
\hline \multirow{2}{*}{ Aspects dealt with } & \multicolumn{2}{c}{ Frequency } \\
\cline { 2 - 3 } & \multicolumn{1}{c}{ Yes } & No \\
\hline Describe emergency procedures & $14(100 \%)$ & - \\
Safe evacuation of people & $12(85.7 \%)$ & $2(14.3 \%)$ \\
Library materials & $11(78.6 \%)$ & $3(21.4 \%)$ \\
List emergency supplies & $10(71.4 \%)$ & $4(28.6 \%)$ \\
Outlines disaster response & $9(64.3 \%)$ & $5(35.7 \%)$ \\
Library building & $9(64.3 \%)$ & $5(35.7 \%)$ \\
\hline
\end{tabular}

The implementation of a disaster plan depends on the assignment of clear responsibilities and lines of authority (Matthews 2003:4). All the 14 libraries with a written disaster plan had an established chain of command to deal with a disaster. Of the 14 libraries with disaster plans, $18(36 \%)$ had a list of emergency telephone numbers posted in every office, nine (64.3\%) did not have a detailed list of procedures to be followed in case of a disaster and six (42.9\%) were not aware of their response policy in the event of a disaster (see Table 2). It is evident from the foregoing that their disaster plans did not adequately provide for efficient response to an emergency.

Simulation exercises are key to equipping people with response techniques once the disaster plan has been formulated. Although testing the plan is more important than the plan itself, there is limited literature that offers guidance on how the tests should be conducted in real life situations (Page 1993:9). However, simulation tests may possibly help the libraries to estimate their response rates and reactions to an emergency. They also test the effectiveness of emergency preparedness plans. One of the outcomes of simulation tests may be the review of the plan. The results show that 5 (10\%) libraries carried out simulated disaster drills. The incidence of disaster drills is lower than the one of Fosu and Akussah (2002: 10) who found that $23.55 \%$ of the libraries they surveyed conducted periodic disaster drills. Other ways of testing the plan include brainstorming sessions and workshops (Muir and Shenton 2002).

Communicating the information on a disaster to employees, suppliers and patrons and the media and general public is part and parcel of response measures (Kahn 2003). Many plans overlook this point during the planning stage (Kahn 2003). That responsibility was not specifically assigned to anyone in all the 14 libraries with disaster plans.

\subsubsection{Recovery measures}

Recovery measures are concerned with salvage operations, counselling staff with physical and mental stress and resumption of normal business. Of the 14 libraries with disaster plans, four had a stock of emergency supplies, three had a list of salvage and recovery experts, and six had lists of supplies and equipment required to deal with a disaster. The questionnaire did not seek much information on recovery measures because recovery plans are usually utilised after the incident (Mansell 2003:25). Another study may possibly be carried out to identify public libraries that have been affected by disasters in order to determine how they responded to the disasters.

However, the important thing about the disaster recovery stage is that it provides a feedback mechanism to the emergency plan. Staff members who would have been involved in disaster recovery share their experiences at this stage, and the information they provide helps the organisation to gauge the effectiveness of its disaster plan. It is in this regard that Line (2002) pointed out that disasters have positive consequences for libraries in that they force libraries to make a radical reappraisal of their disaster plans. Dealing with a disaster may also foster teambuilding and raise the profile of the library through positive publicity (Line 2002).

\subsection{Library security and protection of documents}

Studies from elsewhere demonstrated that theft and mutilation have negative implications for the management of libraries (Burrows and Cooper 1992; Jackson 1990; Lincoln and Lincoln 1986; McCree 2000). Beside the cost implications for the management of the library, theft of library materials has a negative impact on the ability of the library to deliver efficient services. When materials are lost they have to be replaced. That poses a financial burden to public libraries, especially in situations where funding is limited. It also means that library users may go for months without having ready access to the information they need, thus undermining the library's ability to deliver services and justify its existence. Furthermore, replacing lost library materials that are published overseas becomes a nightmare for librarians in many African countries where foreign currency is scarce. Under such circumstances, theft prevention becomes a less costly option than replacing stolen or damaged items.

A number of studies have been conducted on the theft and the mutilation of materials in libraries (Abareh 200I; Ajegbmogun 2004; Alao 2003; Griffith 1978; Burnett 1990). These articles and others that are available in the literature 
tend to concentrate on academic and research libraries at the expense of the public library. The same observation was made by McCree (2000) when studying the levels of theft in public libraries in UK. Scholars from Nigeria dominate most of the literature on the subject in SSA and the focus has persistently been on academic libraries.

Many librarians have problems when it comes to determining the true extent of book loss in their libraries and the materials targeted by thieves (Burrows and Cooper 1992). The current study revealed that 35 (70\%) respondents did not know the number of books that might have been stolen in 2005. Forty percent of the respondents in a study by Lincoln and Lincoln (1986) could not provide an estimate of books that had been stolen the previous year. This figure is close to the $39 \%$ estimate of Burrows and Cooper (1992). On the other hand, McCree (2000) found that $80 \%$ of the respondents could not estimate their losses for the previous year. The reason respondents failed to provide the figures pertaining to their losses is that some of them did not keep data of levels of stock theft in their libraries.

Inventory control or stocktaking helps librarians to monitor loss of library materials (Burrows and Cooper 1992). Stock verification practices are not prevalent in many libraries (Burrows and Cooper 1992; McCree 2000; Retief 2005). Burrows and Cooper (1992) found that $28 \%$ of the libraries they studied never counted their books on an annual basis. Eighty percent of McCree's (2000) respondents did not check their stock regularly. Only 13 (26\%) libraries carried out annual stocktaking of their library collections in the current study. It is surprising that two of the respondents were able to estimate the number of books their libraries had lost the previous year despite the fact that they did not conduct stock checking on an annual basis. Even the KwaZulu-Natal Provincial Public Library and Information Service did not conduct stock verification of its Reference Section on an annual basis. Its Annual Report of 2000 suggested that there was never any stocktaking since 1990 (KwaZulu-Natal Provincial Public Library Service 2000:5). For some reason, no stocktaking was reported in the subsequent annual reports up to 2004.

It is evident that practices at the highest level are not setting a good example for public libraries on the ground. Admittedly stocktaking may be time consuming and require a lot of resources, but the librarian has at his/her disposal other inventory checking strategies such as sampling and computer-assisted stock verification systems (Retief 2005:90) other than shelf-reading the entire collection, which may be tedious. However, one thing that is clear is that the management of theft in public libraries in KZN was limited by unsatisfactory count and inventory control practices.

It is evident from the annual reports of the KwaZulu-Natal Provincial Public Library and Information Service that it takes security of stock seriously. In 2002 it rolled out a programme to put magnetic strips in its entire collection and to install security systems in public libraries. Table 3 depicts a success story as far as the existence of security library systems was concerned. However, the same may not be said about magnetic strips as only 9 (18\%) libraries had magnetic strips in the entire library stock (see Fig. 2). The use of magnetic strips in the entire collection of the public libraries in KZN may curtail the loss of library books through theft.

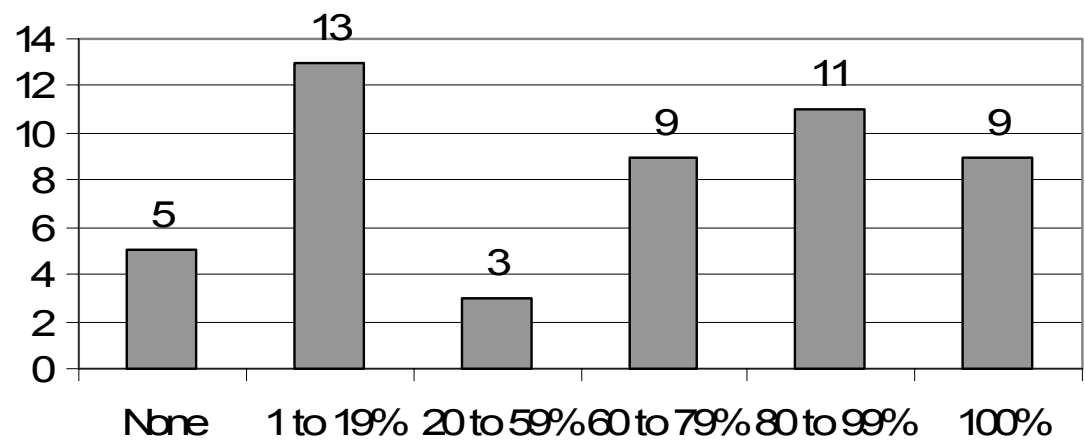

Figure 2 Incidence of library materials with magnetic strips

Imposing penalties for users suspected of theft is one of the ways of deterring thieves from stealing library materials. Although 36 respondents reported that theft was a major problem, only eight $(22.2 \%)$ of those respondents had charged library users for attempted theft. An offender was convicted and sentenced to community service in one instance. Charges against the accused were withdrawn under unclear circumstances in two other cases. Burrows and Cooper (1992) revealed that $70 \%$ of libraries in the UK imposed penalties for users apprehended for attempted theft. 
To wrap up this section, we are going to quote from 'the fourteenth-century abbot known as Umberto Eco' (1983:36) who underscored the central role that the librarian plays in giving access to knowledge and protecting its physical 'containers':

Only the librarian has, in addition to that knowledge, the right to move through the labyrinth of books, he alone knows where to find them, and where to replace them, he alone is responsible for their safekeeping.

4.4. Skilled and knowledgeable staff

The best disaster prevention comes from staff, especially, if they have skills and knowledge of disaster planning and preparedness and security control. To prevent unnecessary loss of materials, institutions need knowledgeable staff and written plans for dealing with emergency situations so that fewer disasters occur and damage is minimised. Trained and knowledgeable staff will ensure that (Kahn 2003; Mathews 2003):

- Awareness is raised on the need to protect documents from disasters and theft;

- Preventive steps to minimise damage are taken;

- Vulnerability analysis and risk assessment to evaluate the types of emergencies that might affect their institution and collections are conducted;

- Security standards are maintained;

- Disaster preparedness plans are developed;

- Health and safety regulations are adhered to during salvage operations;

- Staff have the necessary protective clothing during salvage operations;

- Individuals traumatised by the disaster are counselled

- Salvaging of collections is prioritised; and

- The media is dealt with strategically during and after the disaster.

In the context of disaster preparedness, education and training should target all members of staff and the disaster management team (Alegbeleye 1993:8I). The former should receive general information on disasters, and on response and evacuation procedures. On the other hand, the latter should receive advanced and specialised education and training on disaster planning, and response and salvage procedures. The findings indicated that staff had been instructed in emergency planning in II of the libraries with disaster plans. However, $32(64 \%)$ libraries reported that they did not have staff with expertise in dealing with disaster planning and recovery. Thirty six $(72 \%)$ libraries required basic training in disaster preparedness. A study by Hlabangaan (2006) revealed that none of the information centres in Gaborone had trained their staff on disaster preparedness. It is evident that the situation in KZN was probably better than it was in Gaborone at the time the current study was undertaken.

The KwaZulu-Natal Provincial Public Library and Information Service may not find it necessary to hire consultants to equip staff members who are not on the disaster preparedness team with basic skills in disaster management, as some expertise that may be utilised already exists in-house, albeit in a limited way. Using available internal expertise might go a long way to fostering resource sharing and collaboration among public libraries in $K Z N$ as well as building team spirit in the management of libraries in the province. However, consultants and other continuing education and training activities may possibly be needed in order to impart advanced and specialised skills and knowledge on the subject to the staff members on the disaster management team.

\section{Conclusions and recommendations}

Public libraries in KZN were not adequately prepared for protecting documents against disasters and theft. Furthermore, most of them did not have disaster plans, adequate procedures for disaster response and recovery, satisfactory theft management strategies and sufficient staff with disaster management knowledge and skills.

It is widely acknowledged that the protection of documents based on the principles of disaster preparedness and security control will not stop disasters and theft from occurring, but it may minimise the damage to and theft of documents and help libraries to conduct their normal operations with limited disruptions. In that regard, emergency preparedness plans are fundamental to the protection of library collections, and every library should have such a plan. It is recommended that the National Library of South Africa and LIASA should take an active role in promoting the formulation of context specific disaster management and security control frameworks as well as setting up a national preservation committee to coordinate the activities geared towards protecting the country's cultural heritage.

Librarians need not see drawing up disaster management plans and security guidelines as a daunting task. As Baird (2003) and Ngulube (2005) advised, librarians should not reinvent the wheel when formulating emergency preparedness plans as there are examples of disaster plans found on the World Wide Web and print sources such as Kahn (2003), Morgan and Smith (1997), Ngulube (2005) and SOLINET Preservation Program (2000).

Security may be improved by having a secure building and the use of intrusion perimeter alarms, television surveillance equipment, and electronic 'bugs' or magnetic strips in library materials. Despite some of the security problems identified 
in the preceding texts, Table 3 shows that public libraries in KwaZulu-Natal have taken significant steps to improve the security of library materials in their custody. However, Shuman (1999:20) concedes that good security is very expensive in the light of the financial constraints that public libraries have to operate under. In that regard, there is a need for librarians to strike a balance between having good security and providing the public with the materials and services they require.

The KwaZulu-Natal Provincial Public Library and Information Service should be commended for constructing new library buildings, upgrading or refurbishing the existing structures, furnishing and equipping libraries, supplying all formats of library materials to public libraries, and providing training and professional support. However, the training that is given to libraries should also include disaster management and security control. Otherwise, all the strides that have been achieved thus far will come to naught. A beautiful library with a fully automated information retrieval system may not be able to fulfil its mandate if the materials it is supposed to provide cannot be found and made available to patrons as a result of being lost or damaged. The KwaZulu-Natal Provincial Public Library and Information Service may take its cue from the Massachusetts Board of Library Commissioners (2005) who have a Public Library Emergency Assistance Program that provides supplies, technical assistance, and freezing and drying capabilities to public libraries in the event of a disaster, and trains staff on disaster management.

It is apparent that the results reported in this study were obtained through the use of one data collection method. There is a need to use other data collection methods such as the observation technique and interviews to enhance the validity of the results. Self-completion questionnaires largely depend on how respondents can accurately and honestly report their practices in retrospect. The problem of reporting what is 'politically correct' and socially acceptable cannot be ruled out. Indeed, there were certain inconsistent answers that were given by respondents in certain instances. The observation technique may target the physical structure and layout of the buildings, the risks that the buildings may pose to documentary materials and people, the existence of fire suppression and monitoring systems and security controls, and the incidence of emergency preparedness plans and the pieces of information they contain.

On the other hand, interviews may be used to corroborate evidence collected by the above-mentioned data collection methods. Interviews may also be conducted with the manager of the KwaZulu-Natal Provincial Public Library and Information Service, the two deputy managers and regional librarians of the four library depots in KZN in order to determine the extent to which policy issues and senior management support affect the protection of library materials from disasters and theft.

Further research should be done to assess how the libraries that were once affected by major disasters responded and recovered. Given that the loss of library items may be caused by a variety of factors such as theft, non-return of items and inaccurate records, an investigation into the loss rate of books in public libraries and the nature of the losses may be a worthwhile exercise. For instance, the annual report of the KwaZulu-Natal Provincial Public Library Service (2000:5) attributed the loss of $256 \mathrm{I}$ items over a period of ten years to incorrect records.

\section{References}

Abareh, H. M. 200I. An exploratory survey of book loss, theft and damage in Abubakar Tafawa Balewa University (ATBU), Bauchi, Nigeria. Library and archival security 17(I):33-42.

Akussah, H. and Fosu, V. 200I. Disaster management in academic libraries in Ghana. African journal of library, archives and information science II (I): I-I6.

Ajegbmogun, F. O. 2004. Users' assessment of library security: a Nigerian university case study. Library management 25(8/ 9):386-390.

Alao, I. A. 2003. The effectiveness of library measures against theft and mutilation: an opinion survey. Library and archival security 19(1):29-37.

Alegbeleye, B. 1993. Disaster control planning for libraries, archives and electronic data processing centres in Africa. Ibadan: Option Book and Information Services.

Alire, C. 2000. Resource sharing: a requirement in library-disaster recovery. In: Alire, C. (ed.) Library disaster management and recovery handbook. New York: Neal-Schuman Publishers, pp.56I-573.

Amarasiri, U. 2005. Rising from the wreckage: development of tsunami-affected libraries in Sri Lanka. IFLA journal 3I(2005):307-3I4.

American Library Association. 2005. Hurricane news. [Online]. http://www.ala.org/ala/alonline/hurricanekatrinanews/ katrinanews.htm (Accessed 10 February 2006).

Andiku, S. 2005. Towards disaster preparedness and recovery planning procedures for libraries: a survey of staff and users of the Balme Library, University of Ghana. African journal of library, archives and information science I5(I):75-79.

Babbie, E. and Mouton, J. 200I. The practice of social research. South African edition. Cape Town: Oxford University Press.

Baird, B. J. 2003. Preservation strategies for small academic and public libraries. Lanham, MA: The Scarecrow Press, Inc.

Buchanan, S. A. 2000. Preservation management: emergency preparedness. In: Banks, P. N. and Pilette, R. (eds). Preservation: issues and planning. Chicago: American Library Association, pp. 159-165.

Burnett, C. 1990. Analysis of inventory losses from Long Beach Public Library. Library and archival security 10(I):3-33.

SA JnI Libs \& Info Sci 2006, 72(3) 
Burrows, J. and Cooper, D. 1992. Theft and loss from UK libraries: a national survey. Police Research Group Crime Prevention Unit Series: Paper No. 37. London: Home Office Police Department. [Online] http://www.homeoffice.gov.uk/rds/prgpdfs/ fcpu37.pdf (Accessed I 5 January 2006).

Butler, R. 1986. The Los Angeles Central Library fire. Conservation administration news 27 (October): I - 2, 23, 27.

Clements, D. W. G. 1987. Preservation and conservation of library and archival documents: a UNESCO/IFLA/ICA enquiry into the current state of the world's patrimony. Paris: UNESCO. (PGI-87/WS/I5).

Coates, P. R. 1993. Preservation in South Africa: the present situation. International preservation news 6:9-II.

Eco, U. 1983. The name of the rose. Translated by William Weaver. New York: Warner.

Eden, P., Feather, J. and Matthews, G. 1994. Preservation and library management: a reconsideration. Library management I5(4):5-II.

Eden, P. and Matthews, G. 1996. Disaster management in libraries. Library management I7(3):5-I2.

Feather, J. 1991. Preservation and the management of library collections. London: The Library Association.

Feather, J. and Eden, P. 1997. National preservation policy: policies and practices in archives and records offices. British Library Research and Innovation Report No. 43. West Yorkshire: British Library Board.

Fisk, R. 2003. Islamic Library burned to the ground. Arab news: Saudi Arabia's first English language daily. [Online]. http:// www.arabnews.com (Accessed 16 April 2003).

Fosu, V. and Akussah, H. 2002. Disaster awareness, prevention, preparedness and recovery in special libraries in Ghana. Journal of librarianship and information science in Africa 2002(I): 2-I4.

Fox, L. L. 1998. Disaster preparedness workbook for U.S. navy libraries and archives. Newport, RI: U.S. Navy War College Library.

Griffith, J. W. 1978. Library thefts: a problem that won't go away. American libraries 9(4):224-7.

Groves, R. M., Cialdini, R. B. and Couper, M. P. 1992. Understanding the decision to participate in a survey. Public opinion quarterly 56:475-495.

Harrison, A. 3 April 2002. Re: Meeting announcement-disaster recovery: the Pentagon experience. [Online]. Archives and Archivists Listserv. archives@listserv.muohio.edu (Accessed 3 April 2002).

Harvey, R 1993. Preservation in libraries: principles, strategies and practices for libraries. London: Bowker.

Hlabangaan, K. 2006. Disaster preparedness and security of information resources: the case of information centers in Gaborone, Botswana. Masters thesis. University of Botswana: Gaborone.

Holden, P. 2004. 'Heaven helps those who help themselves': the realities of disaster planning. Journal of the society of archivists 25(I):27-33.

Jackson, M. 1990. Please can we have our books back. Library association record 92(5):359-63

Kahn, M. 2003. Disaster response and planning for libraries. $2^{\text {nd }}$ ed. Chicago: American Library Association.

KwaZulu-Natal Provincial Public Library Service. 2000-2004. Annual reports. Pietermaritzburg: Author.

Law, D. 1999. Disaster and after: an introduction. In: Sturges, P \& Rosenberg, D. (eds). Disaster and after: the practicalities of information service in times of war and other catastrophes. Proceedings of an international conference sponsored by IGLA (The International Group of the Library Association), 4-6 September 1998, University of Bristol. London: Taylor Graham, pp.3-7.

Leedy, P. D and Ormrod, J. E. 2005. Practical research: planning and design. $8^{\text {th }}$ ed. Upper Saddle River, NJ: Pearson Prentice Hall.

Lincoln, A. J and Lincoln, C. Z. 1986. Library crime and security. New York: Haworth. (Also appeared in Library and archival security $8(1 / 2)$, 1986).

Line, M. B. 2002. Management musings 9: extracting pearls from rotten oysters. Library management 23(8/9):435-436.

Lyall, J. 1995. Disaster planning for libraries and archives: understanding the essential issues. In: Arnoult, J., Kremp, V and Musembi, M. (eds). Proceedings of the Pan-African conference on the preservation and conservation of library and archival materials, held in Nairobi on June 2I-25, 1993. The Hague: IFLA, pp. I03-I I 2.

Mansell, H. 2003. The disaster control plan. In: Matthews, G. and Feather, J. (eds). Disaster management for libraries and archives. Aldershot: Ashgate Publishing Limited, pp. I3-40.

Massachusetts Board of Library Commissioners. 2005. Preservation. [Online]. http://www.mlin.lib.ma.us/advisory/preservation/ index.php (Accessed 14 May 2006)

Matthews, G. 2003. Disaster management for libraries and archives - an introduction. In: Matthews, G. and Feather, J. (eds). Disaster management for libraries and archives. Aldershot: Ashgate Publishing Limited, pp. I- I2.

Matthews, G. 2005. Disaster management: sharing experience, working together across the sector. Journal of librarianship and information science 37(2):63-74.

Matthews, G. and Eden, P.1996. Disaster management training in libraries. Library review 45(I):30-38.

Matthews, G. and Feather, J. (eds). 2003. Disaster management for libraries and archives. Aldershot: Ashgate Publishing Limited.

Maúngue, S. A., Mahumane, J. J. and Mangue, A. P. 2003. Impacto das cheias de 2000 nos arquivos públicos de Xai-Xai, Chókwè e Guijá. Paper presented at the XVII Biennial Eastern and Southern Africa Regional Branch of the International Council on Archives (ESARBICA) General Conference on Archives, Society and Good Governance, 22-26 July, Mozambique, Maputo.

Mbaye, S. 1995. Problems of preservation and conservation in libraries and archives of Black Africa. In: Arnoult, J., Kremp, V \& Musembi, M. (eds). Proceedings of the Pan-African conference on the preservation and conservation of library and archival materials, held in Nairobi on June 2I-25, 1993. The Hague: IFLA, pp.4I-44.

McCree, M. 2000. Theft in the public library: An investigation into levels of theft and the impact it has on both service and staff. Masters thesis. The University of Sheffield: Sheffield. [Online]. http://dagda.shef.ac.uk/dissertations/1999-00/mccree.pdf (Accessed 25 February 2006).

Morgan, G. and Smith, J. G. 1997. Disaster management in libraries: the role of a disaster plan. South African journal of library and information science 65(I):62-7I.

Morrow, C. C. 2000. Defining the library preservation program: policies and organisation. In: Banks, P. N and Pilette, R. (eds). Preservation: issues and planning. Chicago: American Library Association, pp. I-27. 
Muir, A. and Shenton, S. 2002. If the worst happens: the use and effectiveness of disaster plans in libraries and archives. Library management 23(3): I I5-123. [Online] http://www.emeraldinsight.com/ (Accessed I5 April 2004).

Murray, K. 2002. Preservation education and training for South African library and archive professionals and students. MBibl. Cape Town: University of Cape Town.

Ngulube, P. 2003a. Preservation and access to public records and archives in South Africa. PhD thesis. University of Natal: Pietermaritzburg. [Online]. http://www.hs.unp.ac.za/infs/thesispn.pdf (Accessed 25 February 2005).

Ngulube, P. 2003b. Putting the horse in front of the cart: the role of disaster planning and security in the protection of documentary materials in Africa. S.A. archives journal 43:58-68.

Ngulube, P. 2005. Disaster and security management in public archival institutions of the East and Southern Africa Regional Branch of the International Council on Archives (ESARBICA) member states. African journal of library, archives and information science 15(I): I5-23.

Ogden, S. 1996. Preservation of library and archival materials: a manual. 3rd ed. [Online]. http://www.nedcc.org (Accessed I9 January 200I).

PABRICA (Pacific Regional Branch International Council on Archives). 2004. Cyclone Heta. [Online]. http:// www.archivenet.gov.au/archives/parbica/CycloneHeta-Niue.htm (Accessed 28 February 2005).

Page, J. A. 1993. Exercising your disaster plans: a tabletop drill. Conservation administration news 54:8-9.

Payne, G. and Payne, J. 2004. Key concepts in social research. London: Sage.

Pybus, R. L. 1998. The management of books in public libraries. West Ashton: The Pybus Partnership.

Ramos, M. J. F. 200I. The situation of public and school libraries in the Republic of Angola. Proceedings of the Pan-African PanArab conference on public and school libraries, held in Rabat on September 19-22, 200I. The Hague: IFLA, pp.96-99.

Retief, E. 2005. The role of inventory control in service quality in a South African academic library. Masters thesis. University of South Africa: Pretoria. [Online]. http://etd.unisa.ac.za/ETD-db/theses/available/etd-092 I 2005-/42340/unrestricted/ O0dissertation.pdf (Accessed 10 May 2006).

Robertson, G. 2005. Postponing Alexandria: dealing with catastrophes and disasters in your library. Feliciter: linking Canada's information professionals I5(6):277-279.

Rogelberg, S. G. and Luong, A. 1998. Nonresponse to mailed surveys: a review and guide. Current directions in psychological science 7:60-65.

Shipman, M. 1997. The limitations of social research. 4th ed. Longman: London.

Shuman, B. A. 1999. Library security and safety handbook: prevention, policies and procedures. Chicago: American Library Association.

SOLINET Preservation Program. 2000. Contents of a disaster plan. [Online]. http://www.solinet.net/preservation/leaflets/ (Accessed I5 June 2004).

South Africa. 2002. Disaster Management Act, 2002. Act No. 57 of 2002. Republic of South Africa Government Gazette, No. 24252.

Sturges, P. 1999. A holistic approach to information services and times of disaster: final thoughts from the Chairman of the Conference. In: Sturges, P \& Rosenberg, D. (eds). Disaster and after: the practicalities of information service in times of war and other catastrophes. Proceedings of an international conference sponsored by IGLA (The International Group of the Library Association), 4-6 September 1998, University of Bristol. London: Taylor Graham, pp. 167-169.

Van der Hoeven, $\mathrm{H}$ and van Albada, J. 1996. Memory of the world: lost memory - libraries and archives destroyed in the twentieth century. Paris: UNESCO.

Waters, P. 1990. Phased preservation: a philosophical concept and practical approach to preservation. Special libraries 8I (I):35-43.

Wellheiser, J. G. and Scott, J. 2002. An ounce of prevention: integrated disaster planning for archives, libraries and records centres. $2^{\text {nd }}$ edn. Lanham, MA: Scarecrow Press. 